\title{
LA FASE DEL IBÉRICO FINAL EN EL ASENTAMIENTO DEL TORRELLÓ DEL BOVEROT (ALMAZORA, CASTELLÓN): DOS PIEZAS CERÁMICAS SINGULARES
}

\author{
POR \\ GERARDO CLAUSELL \\ Museo Municipal de Almassora (Castellón) \\ ISABEL IZQUIERDO * \\ Instituto de Historia, CSIC, Madrid \\ FERRAN ARASA \\ Universitat de València \\ Con anexo de JORDI JUAN-TRESSERRAS \\ Univesitat de Barcelona
}

PALABRAS CLAVE: Cerámica ibérica. Iconografía ibérica. Epigrafía ibérica. Yacimiento de El Torrelló del Boverot (Almazora, Castellón)

KEAY WORDS: Iberian pottery. Iberian iconography. Iberian epigraphy. Site of El Torrelló del Boverot (Almazora, Castellón)

\section{RESUMEN}

Desde finales de 1988 , cuando se retoman las campañas de excavación en el yacimiento del Torrelló del Boverot de Almazora (Castellón), se recuperaron abundantes materiales -fundamentalmente cerámicos- del periodo Ibérico final que cierra cronológicamente la vida del poblado. En este trabajo presentamos dos piezas cerámicas singulares correspondientes a esta fase tardía, documentada a través de la campaña de excavación llevada a cabo en 1995, en la que se trabajó en el área central del asentamiento. El registro obtenido en esta intervención coincide con el proporcionado por un lote de materiales donados al Museo de Almazora por parte de los aficionados que excavaron este poblado a mediados de la década de los setenta.

\section{SUMMARY}

Since the end of 1988 , when excavation was resumed at the Torrelló del Boverot site in Almazora (Castellón), large amounts of material - mostly ceramics - have been recovered, dating from the end of the Iberian period, which, chronologically, marked the end of the village's life. This paper discusses two unusual ceramic pieces from this late period, documented during the excavations that took place in 1995 , undertaken in the central area of the site. The records obtained in this work matches that of a batch of materials donated to the Museum of Almazora by the amateurs who excavated this village in the mid-1970s.

* Becaria postdoctoral por la Comunidad de Madrid. Proyecto 06/0102/99. E-mails: museo.3130@ cajarural.com (G. Clausell), cehi309@ceh.csic.es (I. Izquierdo) y Ferran. Arasa@uv.es (F. Arasa).

\section{INTRODUCCIÓN}

El asentamiento del Torrelló del Boverot (fig. 1) se sitúa al oeste del término municipal de Almazora, en la provincia de Castellón, a $93 \mathrm{~m}$ de altura s.n.m., en las terrazas superiores del río Mijares (Clausell, 1999a). El poblado, que adopta la forma de una colina de entre 4 y $5 \mathrm{~m}$ de altura, se asienta sobre un espolón situado sobre el cauce del río Mijares ${ }^{1}$. Este río, que posiblemente se corresponde con el antiguo Udiva mencionado por Plinio (Nat. Hist. 3, 30), parece haber sido la frontera entre los edetanos, al sur, y los ilercavones, al norte, al menos, en la fase final de la cultura ibérica (Arasa, 1995, 144-149). En este territorio, a lo largo del cauce del Mijares, conocemos la existencia de destacados núcleos de habitación, como Vinarra-gell (Burriana, Castellón) (Mesado, 1974) y de lugares de enterramiento fechados desde momentos antiguos (Clausell, 1997, 21), siendo una importante vía de comunicación entre el interior de las provincias de Castellón y Teruel -Alto Mijares- y la costa marítima mediterránea. A modo de ejemplo cabe señalar el tránsito comercial documentado entre los siglos viII y vi a.C. con el intercambio de recipientes cerámicos elaborados a mano procedentes de otras áreas - Bajo Aragón y curso medio del Ebro- y las importaciones de materiales fenicios cuyo origen se sitúa en las costas de Malaca, convirtiéndose el Torrelló en un redistribuidor de materiales cerámicos en el interior de Castellón.

El yacimiento presenta una superficie total de alrededor de $1400 \mathrm{~m}^{2}$ y el arco cronológico que orien-

\footnotetext{
Sus terrazas se formaron tras la deposición de los aluviones arrastrados por las aguas del río, que al llegar al mar conforma un delta fluvial de cerca de $1 \mathrm{~km}$ de amplitud, que se encuentra camuflado en la actualidad (Sanfeliu, 1985, 53).
} 


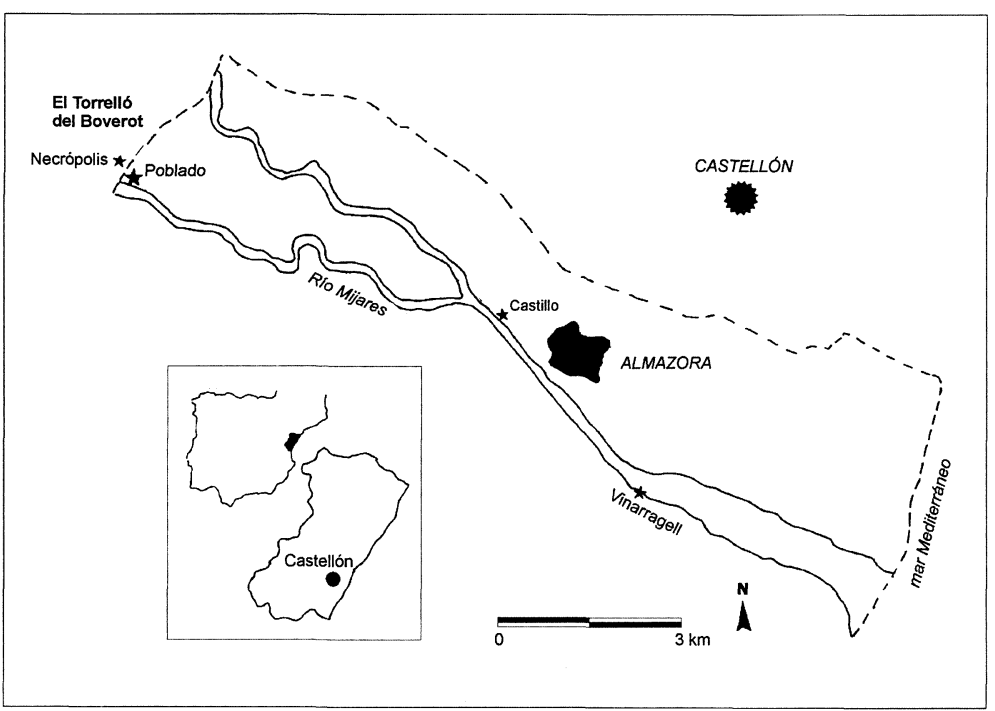

Fig. 1.-Situación del poblado del Torrelló del Boverot (Almazora, Castellón).
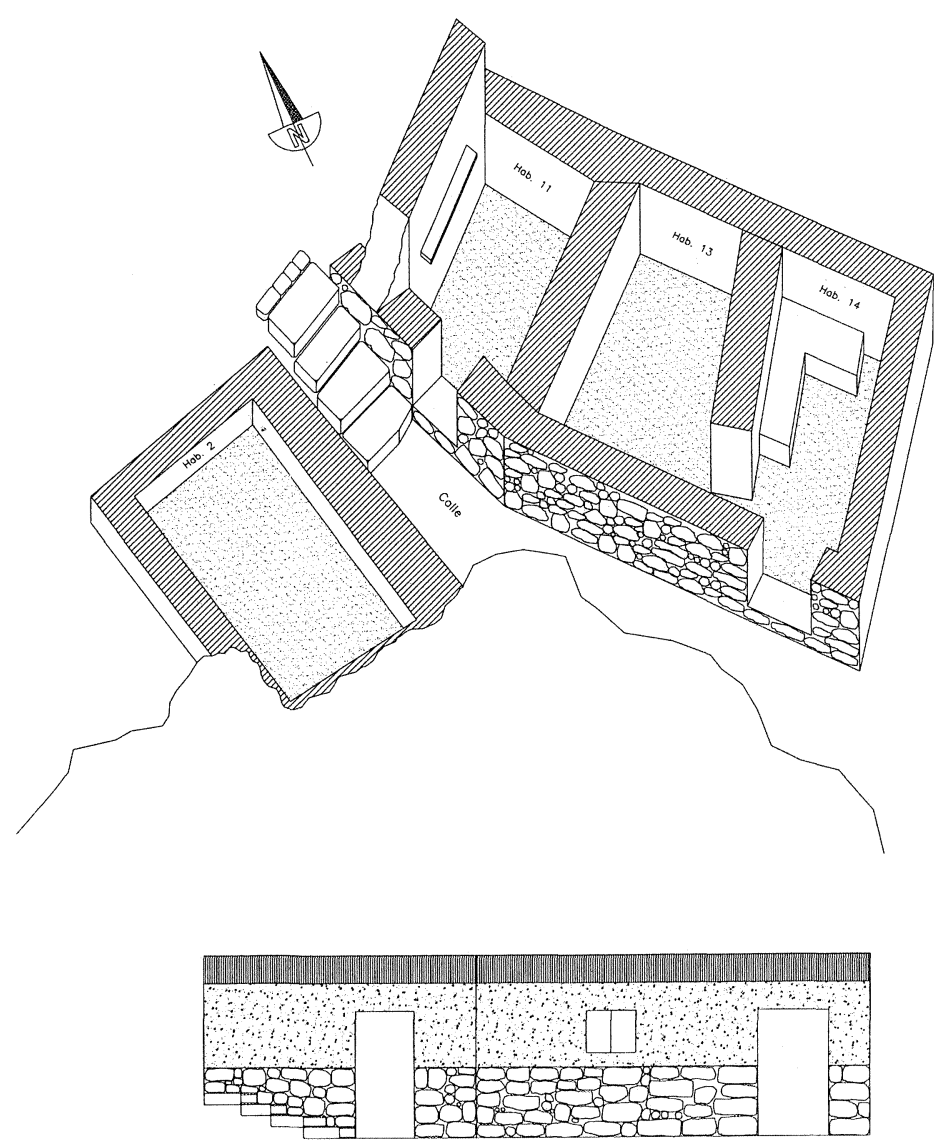

Fig. 2.-Torrelló del Boverot. Planta y alzado de las habitaciones 11-13-14. Escala $1 / 100$. ta el estudio de sus estructuras y materiales se extiende desde el Bronce Medio (1300-1200 a.C.) hasta mediados del siglo II a.C. (Clausell, 1997) con distintas fases de abandono del poblado hasta su definitivo cambio de emplazamiento tras el Ibérico final. El interés de su estudio reside en la variedad y calidad de los materiales que ha proporcionado, su larga perduración y función estratégica en la dinámica del territorio en que se inserta. Las campañas de excavación en curso y los futuros trabajos sobre el yacimiento contribuirán a despejar las incógnitas que en la actualidad plantea este asentamiento. Presentamos en este trabajo una síntesis de los principales resultados de las campañas de excavación realizadas en los años setenta, llevadas a cabo por aficionados locales, así como la excavación de 1995, de cara a la contextualización de los materiales cerámicos, de época tardía, que se analizan a continuación.

\section{LAS CAMPAÑAS DE EX- CAVACIÓN}

LAS INTERVENCIONES EN LA DÉCADA DE LOS SETENTA

Tras el inicio en 1988 de las campañas de excavación en este yacimiento, el Museo de Almazora fue depositario de un lote de materiales procedentes de este poblado, fruto de las excavaciones realizadas entre 1973 y 1975 por aficionados del municipio (Clausell, 1999a, 182). Las piezas -fundamentalmente cerámicas ibéricas - proceden mayoritariamente de la intervención en dos habitaciones y la excavación de diversas catas en el poblado, así como de la recogida de materiales procedentes de las terrazas meridionales del montículo. Además de las cerámicas ibéricas, se 
depositaron vasos elaborados a mano, adscritos al momento final del Bronce medio (Clausell, 1997, 22-27) y otras cerámicas de importación de época romano-republicana (Arasa, 1995, 52). A juzgar por el conjunto de materiales depositado ${ }^{2}$, el lugar en que se inserta El Torrelló parece estar ocupado desde la Prehistoria hasta época medieval.

Las intervenciones de la década de los setenta sacaron a la luz, desde el punto de vista de las estructuras (fig. 2), los vestigios de dos estancias -habitaciones 1 y 2 -, de forma cuadrangular, situadas prácticamente en la cima del montículo, siguiendo una orientación este-oeste. La habitación 1 $(2,65 \times 4,10 \mathrm{~m})$ documenta un nivel del Ibérico antiguo (fines del siglo vI-inicios del v a.C.)y la habitación $2(2,70 \times 4,05 \mathrm{~m})$, delimitada exclusivamente por su parte interna, parece aportar una estratigrafía más completa, según el testimonio de su excavador, evidenciando por encima de un nivel del Bronce Medio un estrato con abundantes materiales posiblemente pertenecientes - por su disposición- a un suelo de ocupación en el que se hallaron la mayor parte de piezas completas, datado entre finales del siglo III y mediados del II a.C., correspondiente al momento final del yacimiento.

Con respecto a las cerámicas ibéricas finas, según la tipología de Mata y Bonet (1992), destacaremos la presencia, dentro del grupo de los grandes contenedores, de ánforas de formas indeterminadas dada su alta fragmentación. Entre ellas figura un fragmento de boca de borde aplanado y engrosado en su interior, con hombro redondeado y finas estrías, tipo I.1.2 de Mata y Bonet, con paralelos ${ }^{3}$ en distintos ejemplares de-cronología tardía del yacimiento de Alorda Park (Sanmartí, Bruguera y Morer, 1999, 280-283). Por otra parte, dentro del grupo de vasos multifuncionales de tamaño medio, el cálato (tipo II.7.1 de Mata y Bonet) es un tipo muy abundante en el repertorio cerámico del Torrelló. Se trata de un recipiente empleado en el comercio marítimo, como se constata en el fondeadero de la propia costa almazorense de Benafeli (Fernández Izquierdo, 1995, 127). El análisis de contenidos efectuado por J. Juan-Tresserras (v. anexo) ha evidenciado la presencia en su interior de frutos carnosos con miel o arrope. Los cálatos del Torrelló sue-

\footnotetext{
${ }^{2}$ Los testimonios más antiguos de ocupación del área son proporcionados por unos fragmentos de sílex (Pascual y García Puchol, 1998, 76) correspondientes al Paleolítico superior final. La datación más reciente la ofrecen unas piezas asociadas a una alquería musulmana, anterior a la conquista de Jaime I en 1234, situada junto al actual poblado del Torrelló.

${ }^{3}$ El tipo anfórico del Torrelló se corresponde con la variante IX B de Oliver $(1994,112)$ del yacimiento castellonense del Puig de la Misericordia (Vinaroz).
}

len adoptar formas cilíndricas; sus bordes son moldurados o planos y presentan una decoración básicamente geométrica - círculos, semicírculos, o teoría de eses-, así como en algunos casos, vegetal. La variante de tamaño pequeño es más frecuente, aunque también se han hallado grandes ejemplares. Los cálatos que presentamos (figs. 3, 4 y 5), forma C-2 de Conde (1992, 129), muestran el ala plana, decorada con el motivo conocido como dientes de lobo. Destaca asimismo la presencia de un gran lebes (figs. 6 y 7) de borde moldurado y base cóncava, decorado con un friso de motivos geométricos —-semicírculos y «cabelleras»-. Junto a la base se representa una línea pintada serpentiforme que aparece «enroscada» a un trazo vertical. Planteamos la hipótesis de que este signo podría representar una marca indicadora del propietario, el productor o, posiblemente, el alfarero o taller donde se fabricó la pieza ${ }^{4}$. La vajilla de mesa está representada a través de platos, páteras y cuencos (III.8.1 y 2 de Mata y Bonet), decorados con motivos geométricos (figs. 8 y 9) - filetes y bandas - en su interior y exterior ${ }^{5}$. Y finalmente, en cuanto a la cerámica tosca o de cocina, señalaremos la presencia de tapaderas con pomo anillado, y algunos bordes, muy fragmentados, de formas indeterminadas, correspondientes tal vez a ollas.

\section{LA CAMPAÑA DE EXCAVACIÓN DE 1995}

En 1995 se inicia la excavación en una nueva área situada al este del asentamiento, que trata de documentar la distribución espacial de las estructuras y verificar la ordenación y datación de los niveles arqueológicos. Los estratos superiores del área excavada, de entorno a $300 \mathrm{~m}^{2}$, evidencian niveles correspondientes al periodo Ibérico tardío ${ }^{6}$. Desde el punto de vista arquitectónico (fig. 2) fueron definidas tres estancias, una de pequeñas dimensiones y forma rectangular alargada - habitación 11- y otras dos que conforman un recinto mayor subdividido - habitaciones 13 y 14 - Esta última presentaba un banco corrido adosado al muro divisorio de ambos receptáculos y al lienzo norte. Estructural-

\footnotetext{
${ }^{4}$ Del mismo modo podrían ser interpretados otros signos sobre recipientes cerámicos, como la flecha con doble punta pintada en el pomo de una tapadera del poblado de la Lloma del Manoll (Bonet y Mata, 1997, 45).

5 En la tipología de Oliver (1994) forma parte de la variante B.1 dentro del tipo III.

6 Se hallaron, no obstante, materiales residuales con cronologías de la Edad del Bronce, como el brazalete pulido en piedra arenisca, correspondiente a un tipo conocido en el Bronce Medio, como en el poblado de la Lloma de Bechí (de Pedro, 1998, 100).
} 




Fig. 3.-Cerámica ibérica fina: cálato.

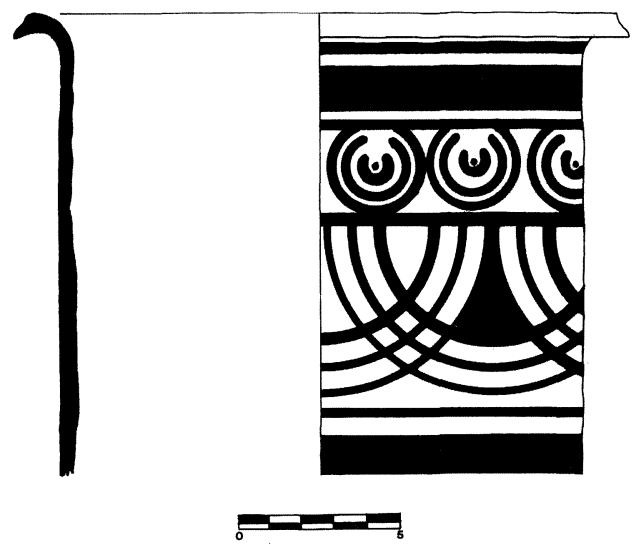

Fig. 4.-Cerámica ibérica fina: cálato.
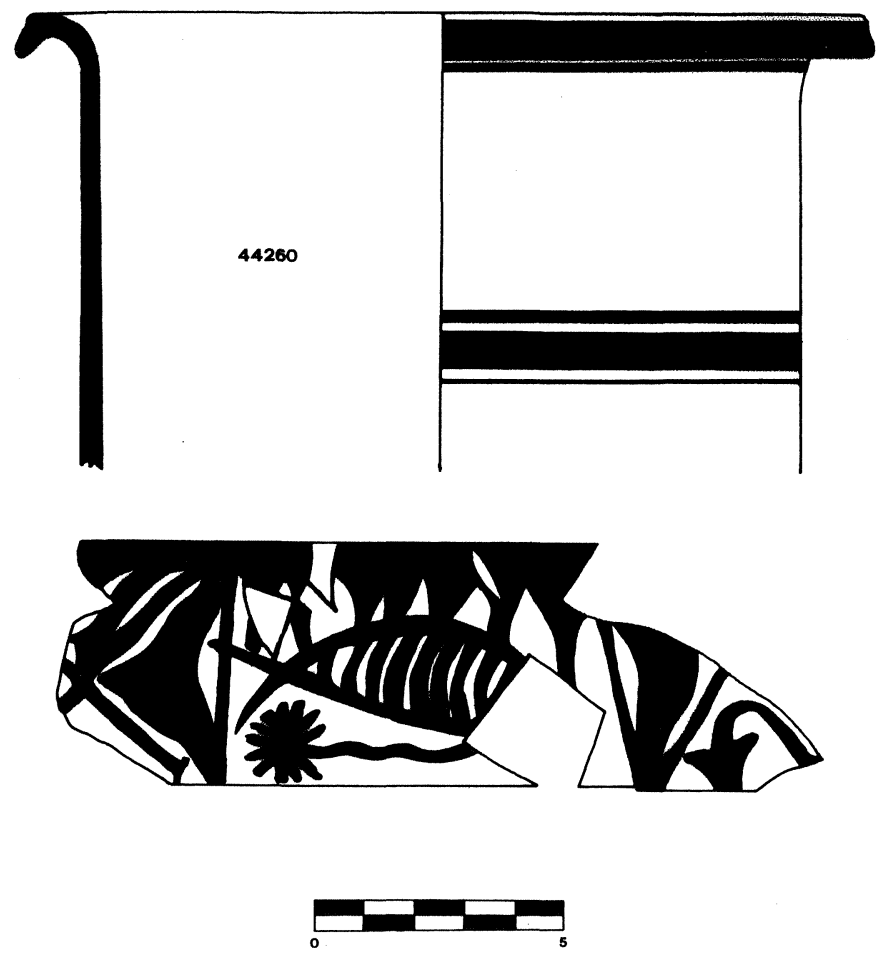

Fig. 5.-Cerámica ibérica fina: cálato. 


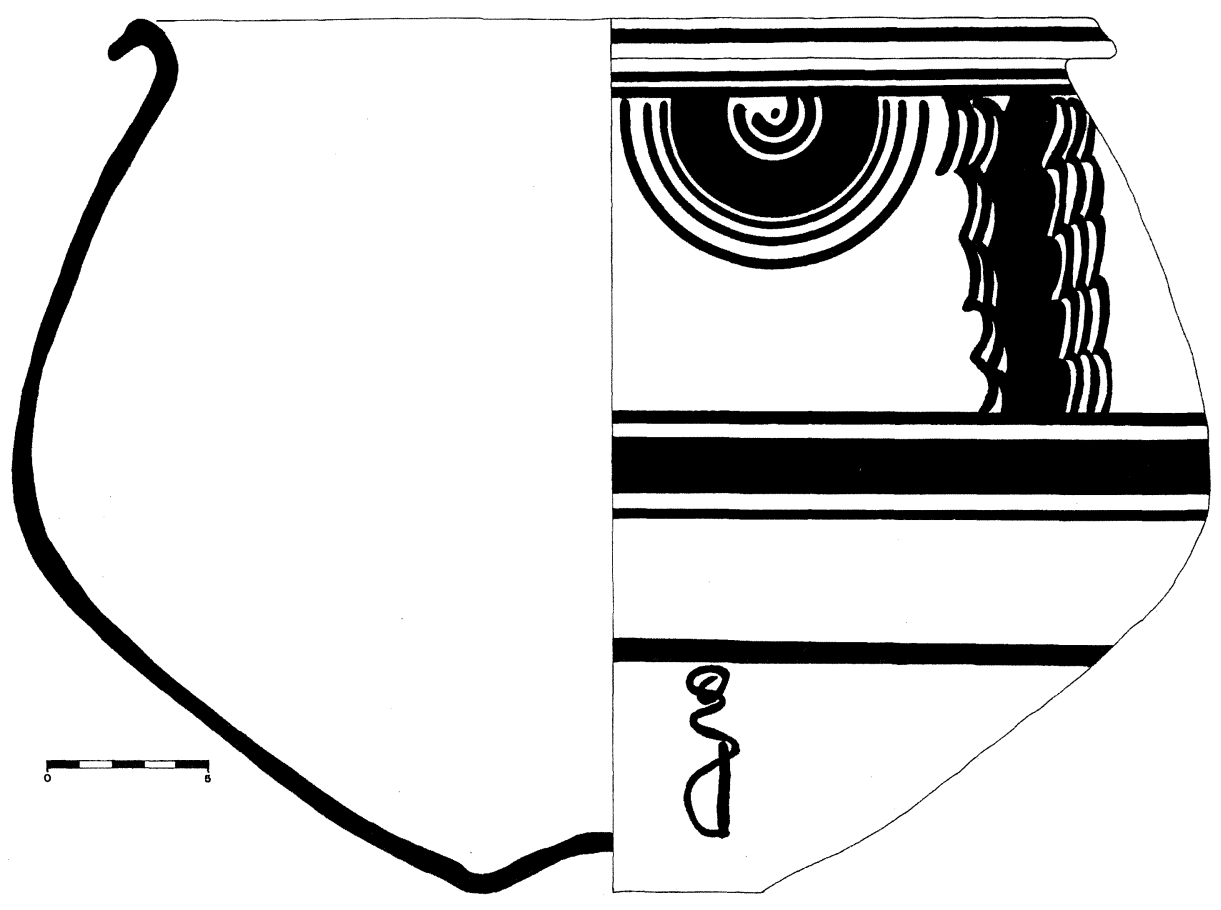

Fig. 6.-Cerámica ibérica fina: lebes.

mente, estas estancias parecen construirse simultáneamente, levantando primero los muros principales - exteriores, norte, sur, y oeste-, dotados de un zócalo de mampostería de $1 \mathrm{~m}$ de altura aproximadamente, al que se adosa el muro medianero entre las habitaciones 11 y 13 y el divisorio entre la 13 y la 14 , realizados con la misma técnica constructiva. Sobre este basamento se eleva un muro de tapial, cuyas caras exteriores posiblemente estuvieran revocadas. Las viviendas presentan una salida a la calle de $110 \mathrm{~cm}$ de anchura, en la que se evidencian restos de una escalera con cuatro peldaños.

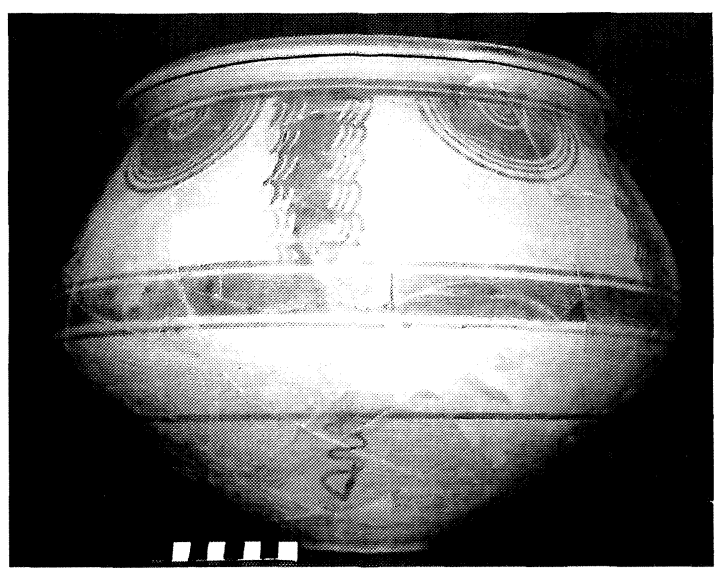

Fig. 7.-Lebes ibérico. (Foto G. Clausell).
En el área excavada se han registrado abundantes materiales, fundamentalmente en la habitación 11 (fig. 10) y en la calle central, constatándose un mismo nivel de abandono, que apunta a un saqueo repentino y violento, dado el estado de conservación y la fragmentación de las piezas ${ }^{7}$. Entre las cerámicas ibéricas, destacamos por su abundancia la presencia de cálatos, ánforas y finalmente dos formas de imitación del tipo cúlica-esquifo, uno conservado casi completamente (fig. 11) y otro con una inscripción pintada en su borde, cuyo estudio se presenta monográficamente más adelante. Otras formas presentes en el repertorio cerámico de esta estancia son los platos, cuencos, caliciformes, jarros o lebes, decorados generalmente con motivos geométricos pintados. Más excepcionalmente se desarrollan temas vegetales o fitomorfos ${ }^{8}$, e incluso figuraciones animales -se ha documentado la presencia de aves y pájaros- y humanas. Presentamos a continuación el estudio de una de estas piezas singulares, correspondiente a un fragmento con escena figurada.

7 Se han hallado fragmentos de una misma pieza, tanto en la calle, como en el interior de la habitación 11.

${ }^{8}$ La decoración vegetal está presente asimismo en una de las tumbas - la núm. 20- de la necrópolis del poblado, cuyo estudio se ha presentado monográficamente (Clausell, 1999b). 


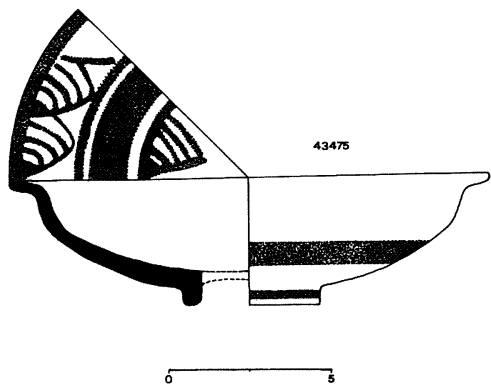

Fig. 8.-Cerámica ibérica fina: plato.

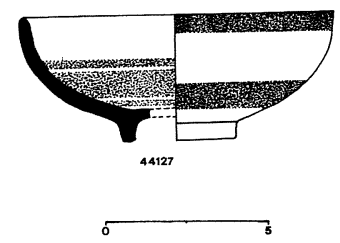

Fig. 9.-Cerámica ibérica fina: cuenco.



Fig. 10.-Excavación de la habitación 11. (Foto G. Clausell).

\section{VASO CON ESCENA DE FLAUTISTA Y DANZANTE}

\section{ANÁLISIS Y DESCRIPCIÓN}

Se trata de un fragmento ${ }^{9}$ perteneciente al galbo de una tinaja o, más bien, un lebes ${ }^{10}$. La decoración del fragmento es pintada de color rojizo, monocroma, compleja y figurada (fig. 12). Muestra una escena principal (fig. 13) con dos personajes, uno femenino y otro masculino, enmarcada mediante

${ }^{9}$ Agradecemos especialmente las sugerencias de C. Aranegui (Universitat de València), H. Bonet (S.I.P., Valencia) y R. Olmos (CSIC, Madrid) sobre la lectura de esta escena.

${ }_{10}$ Su pasta, muy depurada, es de color anaranjado, de cocción homogénea, con fino y escaso desgrasante de color blanquecino. El tratamiento de sus superficies interior y exterior, de color marrón claro, es un simple alisado. Sus dimensiones son: $15,5 \mathrm{~cm}$ de altura máxima $\times 18,2 \mathrm{~cm}$ de anchura máxima. motivos geométricos y vegetales ${ }^{11}$. Por la parte inferior de la escena se observa la conocida combinación de signos geométricos «filete-banda-filete»y, en la superior, un filete sobre el que se apoya un signo fitomorfo - ¿un roleo?-, parcialmente con-

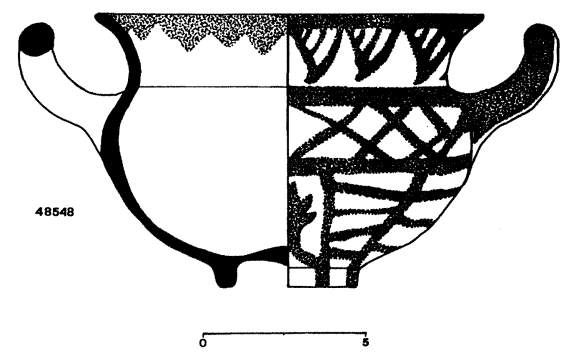

Fig. 11.-Cerámica ibérica fina: imitación de cílica-escifo.

1 El rellenado de las figuras principales ha sido realizado en pasadas sucesivas, de manera no uniforme, apreciándose en puntos diversos acumulaciones de pintura. 
servado. A ambos lados del tema central, delimitándolo, se representa, a la derecha, un motivo vertical de forma rectangular con reticulado sobre el que se apoya otro motivo consistente en una banda inclinada de la que penden trazos cortos, horizontales y paralelos, que está parcialmente fragmentado. A la izquierda, tras la figura femenina, se ha dispuesto un motivo vertical formado por dos filetes, en cuyo interior aparece una serie de rombos.

En el espacio articulado por estas formas geométricas y vegetales

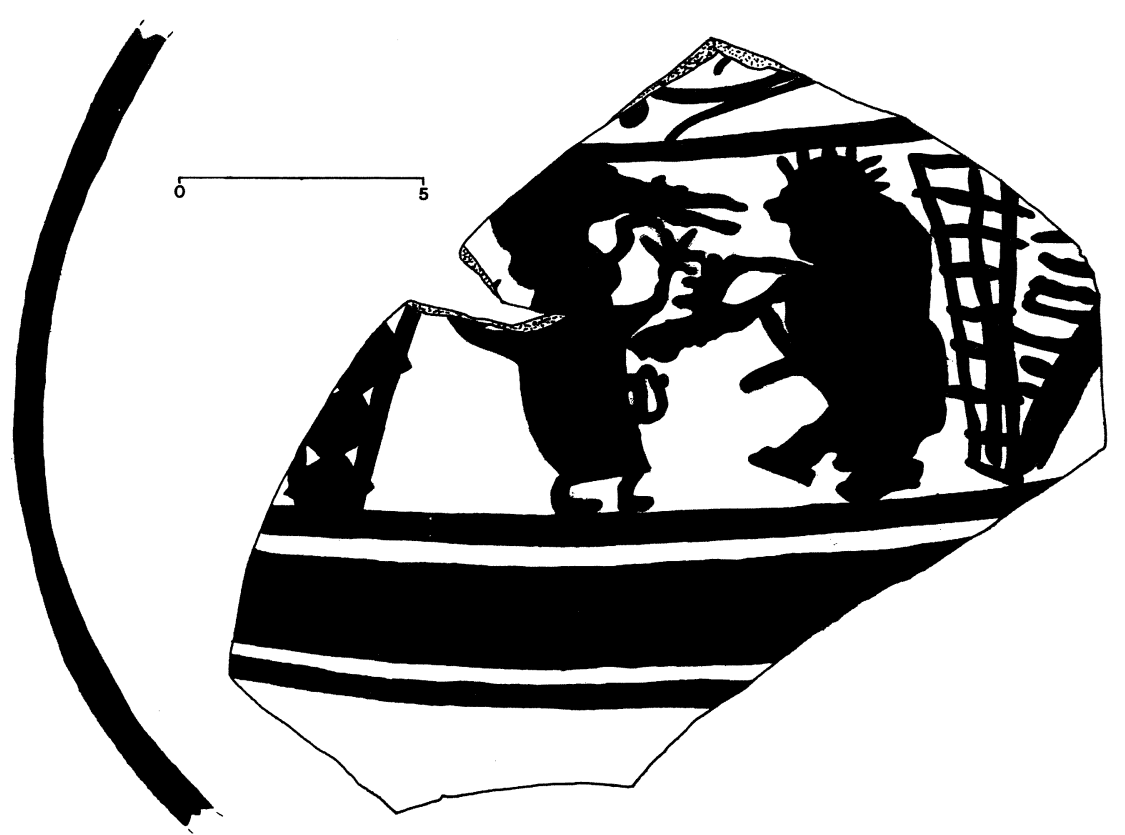

Fig. 12.-Vaso ibérico con escena de flautista y danzante. se desarrolla una singular escena protagonizada por dos personajes pintados según la técnica de las figuras planas. A la izquierda se representa a una mujer que tañe la doble flauta o diaulós, de tubos divergentes $\mathrm{y}$, en este caso, longitud similar. Aparece de perfil; se representa el busto y viste túnica o manto que llega por debajo de la rodilla. El rostro de la figura se muestra exageradamente alargado, un tanto deformado, fundiéndose con el instrumento musical que prolonga su perfil. Se observa la convención de la frente, aunque ojos, nariz y boca aparecen confundidos con los tubos y la mano izquierda. Parece presentar un tocado abultado sobre su cabeza y podría estar

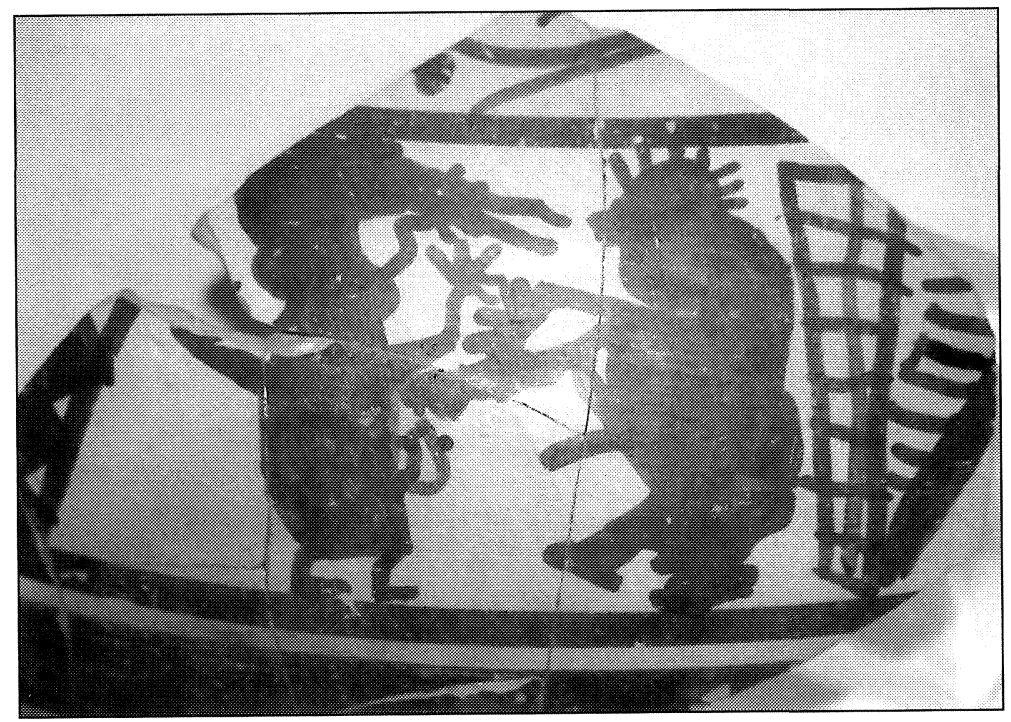

Fig. 13.-Vaso con escena de flautista y danzante. (Foto G. Clausell). velada o cubierta por un elemento de difícil definición. Se destaca la representación de los brazos ${ }^{12}$, alzados, con las manos abiertas y los dedos extendidos, según la disposición que exige el instrumento. Los pies se representan de perfil, dispuestos en

${ }_{12}$ El brazo derecho aparece flexionado y los dedos, enérgicos y de proporciones exageradas, apenas rozan los extremos del aulós. El brazo izquierdo se muestra también doblado mediante la convención de un trazo sinuoso y los dedos, grandes y extendidos, se sitúan directamente sobre los tubos.

paralelo y apoyados sobre el filete inferior que enmarca la escena. El pie delantero -y en menor medida el trasero - aparecen ligerísimamente elevados. Un elemento alargado y doblado, indeterminado, es apreciable por la parte posterior de la figura, a la altura de la cintura. La rotura del fragmento impide precisar su definición. Del mismo modo, por la parte anterior de la figura surge un elemento encadenado que se pinta sobrepuesto a la indumentaria, a la altura de la parte superior de las piernas. Se 
muestra, en síntesis, una figura femenina de perfil que tañe el aulós. Presenta una indumentaria particular, una túnica gruesa envolvente o un pesado manto que cubre casi por completo su cuerpo, aunque no llega a los pies. De la auletris sobresale por detrás un elemento indeterminable de dimensiones considerables que podría ser un ala, o más bien, otro tipo de elemento prendido al hombro o la espalda de la figura. Los trazos en forma de cadena que se destacan sobre la túnica por la parte delantera constituyen probablemente un complemento metálico de la indumentaria ¿una hebilla de un complejo cinturón, suspendido de su cuerpo?

Frente a la tañedora de aulós se representa un personaje masculino caracterizado con algunos rasgos animales que danza al son de la música. Se trata de una figura masculina, extraordinariamente gruesa, de rasgos humanos aunque disfrazados o transformados en zoomorfos, aspecto apreciable en su cabeza, cuerpo y extremidades. Se muestra también de perfil con la pierna izquierda flexionada y la derecha extendida y levantada, apoyándose «de puntillas» sobre el pie izquierdo; el derecho aparece completamente elevado hacia arriba. Los pies están calzados o representados de manera destacada, con una suela o planta plana, al modo de ¿pezuñas? El cuerpo es de proporciones exageradas y apenas se distinguen cuello, cintura, ni torso, apareciendo confundidos en una masa abultada que únicamente se diferencia en el perfil, al final de la espalda — «cargada» y voluminosa- y en el arranque de las piernas, gruesas y muy cortas. Es difícil precisar la definición de sus extremidades superiores. Uno de los brazos aparece. elevado con una gran mano abierta, exagerada, de tres o cuatro dedos muy gruesos que vienen a unirse con los dedos de la mano derecha de la flautista. Otro de los extremos que sobresalen del personaje viene a unirse a otro elemento, alargado, de mayores proporciones que podría interpretarse, bien como parte del propio brazo, mal trazado, voluminoso y desproporcionado, o más bien como un atributo, central en la escena, que portara la figura, al modo de clava o instrumento ¿musical?, que se une a la figura femenina.

La representación de la cabeza de este danzante es singular. En el perfil se observa una mandíbula inferior de grandes proporciones que aparece confundida con el torso y, directamente, por encima del brazo. La nariz se presenta exageradamente grande, casi convertida en un hocico de animal, de forma cuadrangular, alto y recto. Sobre este hocico se representa un abultamiento, tal vez correspondiente al ojo y, sobre la cabeza, muestra un tocado con penacho de siete trazos gruesos, cortos y rectos que se disponen sobre la parte superior y posterior, al modo de crin. Aparece, en definitiva, un danzante masculino, pesado y grueso, con ciertas características zoomorfas en lo que se refiere a forma y proporciones del cuerpo, así como determinadas convenciones en el perfil de su cabeza y cuerpo. Nuestra primera impresión al analizar la escena fue considerarlo desnudo e itifálico, sin embargo se plantean diversas incógnitas derivadas de una observación minuciosa del fragmento, relativas a la desnudez de la figura. Más que desnudo, este personaje parece estar cubierto con una pesada indumentaria o piel que cubre la mayor parte de su cuerpo, apenas distinguible por el estilo y la técnica de la representación. Según un análisis minucioso de los recorridos del pincel y la aplicación de la pintura, la mostración del sexo queda cuestionada también por la presencia de un elemento cruzado que parece ir ceñido a su cuerpo y sobresale por la parte anterior de la figura. Más bien parece que el personaje presenta un complemento flexible en su indumentaria que se representa doblado y prendido al cuerpo.

\section{LAS CONVENCIONES FORMALES DE LA REPRESENTACIÓN}

La técnica de la representación condiciona el estilo y la forma. En este caso, llama la atención la aplicación de pintura plana en los personajes, en los que se invierte gran cantidad de color rellenando su silueta completamente. La elección de esta técnica revela el interés del pintor por mostrar únicamente una figura genérica y no detalles de la indumentaria, el rostro o cuerpo de las figuras. Se trata, casi, de sombras chinescas perfectamente delimitadas en su contorno. No se han dejado en reserva, como sucede en otras producciones cerámicas de vasos figurados con decoraciones complejas, determinados adornos de la indumentaria o partes del rostro especialmente destacadas como los ojos. La definición de la indumentaria y las extremidades, sobre todo en el caso del personaje masculino, no está lograda. El artesano parece más interesado por mostrar volúmenes o acción, en lugar de precisar sus rasgos específicos. Hay un énfasis en el movimiento agitado de los brazos o la pierna levantada del danzante, así como la mostración de los dedos, grandes y abiertos, de la flautista que se afana en su instrumento. No se observa una técnica depurada en la representación, sino la voluntad de reflejar un tema concreto, en este caso, de música y danza, como si de un encargo se tratara, con un código restringido de lectura. 
Este fragmento, dentro del técnica de las figuras planas o silueteadas, parece un tanto alejado de la calidad, en la ejecución y la técnica, que exhiben las cerámicas edetanas ${ }^{13}$. Sin embargo, los rasgos generales de la composición, de la representación o detalles concretos como los trazos rígidos que aparecen sobre la cabeza del personaje masculino, los dedos de las manos en ambas figuras, entre otros (vid. infra) sí se reconocen en las cerámicas del cerro de San Miguel de Liria. El artesano-pintor del vaso está familiarizado con los repertorios temáticos de Liria y determinadas convenciones de las representaciones figuradas, sin embargo, la plasmación de la escena de Almazora es singular y no se ajusta exactamente a las producciones de los talleres edetanos identificados. De estas mismas cronologías Ibérico tardío- y sin alejarnos del territorio del Camp de Túria en los paralelos, hemos de señalar la representación de dos personajes afrontados, delimitados también por elementos geométricos con reticulado, pintados de manera esquemática, casi ingenua, sobre un enócoe del Puntal dels Llops de Olocau en Valencia (Bonet y Mata, 1981, 69, fig. 28). La escena, alejada en el estilo del fragmento castellonense, se inscribe en una incipiente serie de cerámicas ibéricas de época tardía con figuración, singulares y originales en lo que se refiere a su tema e interpretación, aunque ejecutadas con un estilo tosco, no muy depurado ${ }^{14}$.

Por otra parte, la escena que muestra este fragmento se desarrolla en un espacio articulado por motivos geométricos. Un espacio perfectamente de-

${ }^{13}$ Este estilo de las figuras planas ha sido bien referenciado en las cerámicas de Liria (Bonet, 1995, fig. 219 y ss.) con ejemplos destacados como el «vaso con procesión y figura fálica» del departamento núm. 16 (Ballester et alii, 1954, 51 , fig. 35 ; Bonet, 1995, 122, fig. 51 y 219) o la escena de la «recolección de granadas» por unos hombrecillos de singulares cuerpos de la gran tinaja del departamento núm. 15 con temas de caza y pesca (Bonet, 1995, lám. XXII, fig. 43). Estos extraordinarios vasos muestran un arte definido por la elección de una técnica precisa.

14 Dentro de esta serie tardía - en el contexto de los siglos II-I a.C.- se incluye un fragmento figurado de la necrópolis de El Cigarralejo (Mula, Murcia) donde se representa un personaje masculino estante de perfil con la técnica de las figuras planas (Maestro, 1989, 313-314, fig. 113). En el propio territorio castellonense, en el asentamiento de la Torre de Onda de Burriana, se documentaron dos cálatos con figuraciones de jinete, asociados a la fase republicana ( $E a$ dem, 77), así como un vaso decorado con peces (Arasa, 1987, 47). Igualmente en El Solaig (Bechí) son conocidos dos fragmentos con jinete lancero y caballo del estilo de Liria (Mesado y Sarrión, 2000, fig. 6). Otras figuraciones procedentes de la comarca de La Plana corresponden al Castell de la Vilavella - pez-, La Punta de La Vall d'Uixó - ave y cánido-. Al norte de este territorio se destacan los yacimientos de el Mas de Víctor de Rosell - ave- y el Puig de la Misericordia de Vinaroz — peces y ave- limitado, cuadrangular, casi asfixiante, donde las figuras aparecen «encajadas» ${ }^{15}$. No se trata tanto del horror vacui que manifiestan algunas decoraciones figuradas de vasos ibéricos, sino de la creación, mediante la pintura de tipo geométrico, de un recinto cerrado donde tiene lugar una escena singular. Tal vez los motivos en forma de retícula o con rombos, además de esa función delimitadora del tema, tuvieran otro tipo de significado, desconocido, incluso la trasposición con algún elemento «real»¿una puerta, un paramento ligero, una jaula?-. Otra cuestión en relación con el espacio de la escena es la creación de un juego de opuestos, en lo formal y en la lectura metafórica, rico y complejo. Se crean dos realidades integradas en una: por un parte, el propio espacio de la flautista y, por otra parte, el del personaje masculino danzante. En la escala general de la representación, ambos aparecen prácticamente igualados; en las proporciones, también. Sin embargo queda planteado un interesante juego de opuestos - femenino vs. masculino, música $v s$. danza, incluso, naturaleza humana vs. naturaleza animal- a valorar en la lectura global de la imagen (vid. infra).

UNA ESCENA IBÉRICA DE MÚSICA Y DANZA EN EL CONTEXto DEL MediterRáNeo

La flautista tañe un doble aulós de tamaño considerable con sus enormes manos. Incluso, podría seguir el ritmo de la música con un ligero movimiento de pies. No es posible apreciar los carrillos, las cintas de cuero que unían los tubos al rostro, o la phorbeia, como en el conocido vaso de El Cigarralejo (Mula, Murcia) ${ }^{16}$. La iconografía de la auletris es bien conocida en Iberia, a través del monumento de Osuna (Olmos, 1992, 136) donde se labran en caliza los carrillos hinchados de la protagonista. Pero sin duda, la imagen de la flautista ibérica (Castelo, 1989) presenta extraordinarios ejemplos en los vasos con decoración figurada de San

15 Los tocados de los personajes protagonistas de la escena están en contacto con el filete superior; sus pies se apoyan en el filete inferior. A derecha e izquierda los motivos geométricos llegan a «rozar» las figuras: en el caso del personaje masculino es evidente; en el caso del femenino no es apreciable por la rotura del fragmento.

${ }^{16}$ En una de las figuras de la crátera ibérica con procesión de guerreros de la necrópolis de El Cigarralejo de Mula se desarrolla una escena compleja en la que dos jóvenes tocan la flauta y la lira (Cuadrado, 1990). El flautista de este vaso tiene los carrillos pintados en negro para sugerir así que están inflados. Incluso podría observarse en su rostro la representación de las cintas unidas al instrumento, aspecto no apreciable en la imagen de Almazora. 
Miguel de Liria donde se muestra una serie de procesiones rituales, exhibiciones, desfiles y competiciones acompañadas con música y danza, en las que participan hombres y mujeres ${ }^{17}$, vestidos con atuendos festivos (Aranegui, 1997, figs. 48-51). Del mismo modo, en uno de los vasos con decoración figurada del importante asentamiento de La Serreta de Alcoy (Alicante) aparece una auletris velada, en una escena de combate entre infantes (Llobregat, 1972, Lám. XII; Nördstrom, 1969-1973, 165-166, láms. 16-18). El cordón terminado en borlas o colgantes que porta la flautista, posiblemente juvenil, de La Serreta ${ }^{18}$ ha llevado a plantear la correspondencia con una especie de tintinabulum o sonaja, que sonaría con el movimiento de la figura (Ruano, 1987, III, 140-141, fig. 1 bis). Finalmente, es conocida otra representación de flautista procedente de la urna cineraria con pugilistas o danzantes afrontados a un ánfora de Torredonjimeno (Jaén) (Olmos, 1987) que desarrolla el tema del certamen atlético o juego funerario en honor del difunto. La imagen de la flautista del Torrelló de Almazora, por tanto, siendo particular en la técnica y las formas de representación, se integra en una serie iconográfica bien documentada, donde la mujer, a través de la música, participa en ritos funerarios - Osuna-, ceremonias públicas, desfiles cívicos o rituales - Liria-, como aspectos mejor conocidos, y apunta otras posibilidades de interpretación.

Con respecto al personaje masculino del vaso de Almazora, éste es particularmente interesante puesto que constituye una imagen excepcional en la combinación de su escala, representación, atributos y gesto. Son singulares sus rasgos formales, el volumen considerable y la caracterización animal de su cuerpo. Parece ejecutar una danza, siguiendo el ritmo de la flauta, que exige la disposición estática y

17 En las escenas rituales de Liria se representan cortejos precedidos por una mujer que toca la doble flauta, como en el conocido «vaso de la danza guerrera» (Ballester et alii, 1954, 60, fig. 44; Bonet, 1995, 176, fig. 85; Aranegui, $1997 \mathrm{a}$, fig. 47), donde los guerreros combaten en duelo al son de la música, o el vaso llamado «de la sardana» (Ballester et alii, 1954, 36, fig. 20; Bonet, 1995, 87, fig. 26; Aranegui, 1997a, fig. II.50), donde se desarrolla una danza colectiva de hombres y mujeres. En las flautistas de Liria se ha sugerido, además, la representación de «cascabeles» suspendidos del tocado o vestido para dar más ritmo a la escena musical (Aranegui, 1997a). Parte del elemento colgante que porta la auletris de Almazora sobre su vestido podría tener una funcionalidad, hipotéticamente, similar.

18 Procedente de este mismo yacimiento, aunque evocando un contexto sagrado, en la placa de terracota con diosa que amamanta a dos niños se ofrece la imagen de dos flautistas (Llobregat, 1972, fig. 15; Olmos, 1992, 127). En el centro de este grupo se muestra la diosa de la fecundidad. A su izquierda, dos flautistas — un adulto y un niño- tocan el instrumento de tubos desiguales. rígida de la parte superior de su cuerpo, la agitación de brazos y el levantamiento ¿alternativo? de piernas. Tal vez el atributo, difícilmente identificable que porta con una de sus manos - ¿una maza o un instrumento musical que seguiría el ritmo de la flauta?- complementaría la ejecución de algún paso de su danza. La iconografía de este personaje cuenta, sin embargo, con paralelos puntuales en otras imágenes ibéricas en lo que se refiere al tocado, su volumen o el gesto de la danza. Sobre su cabeza muestra unos trazos en forma de crines, que podrían recordar, en parte, al tocado que muestra el héroe que se enfrenta a la esfinge en un vaso cerámico de la necrópolis del Corral de Saus de Mogente en Valencia (Izquierdo, 1995) o, incluso, uno de los relieves del monumento funerario de Osuna (Sevilla), donde aparece un guerrero con un tocado parecido ${ }^{19}$ (Olmos, 1992, 132; Rouillard, 1997, 28-32). Interesa, a través de estos ejemplos, observar la asimilación de estos singulares tocados con rasgos zoomorfos. En el ejemplo de Almazora, el personaje masculino, más que un casco o tocado sobrepuesto, parece presentar en su cabeza un «peinado» o las crines que contribuyen a su caracterización como animal, de tipo indeterminado, tal vez un oso o jabalí.

$\mathrm{Si}$ consideramos a este personaje desnudo, rico es el catálogo de imágenes masculinas ibéricas procedentes, principal aunque no exclusivamente, de contextos sacros y funerarios ( $c f$. Marco, 1990, 331332). La serie de exvotos en bronce itifálicos, procedente de ambientes sagrados, ofrece ejemplos, como los pequeños guerreros ${ }^{20}$ del santuario de Castellar de Santisteban (Jaén) (Nicolini, 1973, pl. IIIa, c). Aunque las mejores imágenes proceden de santuarios o tumbas, los contextos de hábitat también documentan el tema del varón desnudo, tal y como refleja la cerámica de Liria, a través de un singular ejemplo en el «vaso con procesión y figura fálica» (Aranegui, 1997, fig. II.43), en el que se desarrolla una procesión ritual y tal vez sacrificial, donde se observa un personaje desnudo saltando, al modo de un sátiro. Sin embargo, ya hemos manifestado nuestras dudas respecto al carácter desnudo del

19 Estos tocados se han relacionado con hipotéticas pieles de animal a juzgar por la aparición de pequeños «cuernecillos» y las crines apreciables en la parte superior y tras la nuca. Ya García y Bellido (1943, 93-102, lám. XVIII-XXI) cita, con respecto al casco de los guerreros de Osuna, las referencias de autores clásicos como Apiano (Iber., 67), Estrabón (III, 3,6, c. 154) y Diodoro (V, 33), que aluden a un casco con cimera volante de crines de caballo. Por otra parte, en el llamado «vaso de los cabezotas» de Liria (Ballester et alii, 1954, 44, fig. 28, lám. XLIII) también aparecen dos «cuernecillos» como remate de un casco masculino.

${ }^{20}$ La desnudez aquí se asocia a un ritual propiciatorio de la fecundidad (Olmos, 1992, 113). 
personaje de Almazora. Tal vez la lectura de esta figura debe ir guiada por su carácter travestido en animal y su actitud danzante. La gruesa envoltura o piel sobre el cuerpo, el perfil de su rostro y sus gestos podrían poner de manifiesto una intención mostrativa, casi teatral.

Conocemos ejemplos de danzas ibéricas ( $c f . s u$ pra), de manera destacada, de nuevo, en los vasos de Liria, como en el llamado «vaso del hombre de la sítula o de los bailarines» (Ballester et alii, 1954, 61-64, figs. 48-54; Bonet, 1995, 100, fig. 35; Aranegui, 1997, fig. II. 46-48), donde se muestra una danza de guerreros que ejecutan un ejercicio dirigido por el sonido del aulós que toca una mujer. Del mismo modo en la caja funeraria de Torredonjimeno (Jaén) se representa una flautista y dos danzantes (Blázquez, 1983, 170-171 y 210). El personaje del vaso que estudiamos aquí no se integra en ningún cortejo o procesión, tal y como vemos en Liria, o emparejado, como en la urna de Torredonjimeno, sino que aparece sólo frente a la flautista. Sin duda, es el protagonista principal de la escena ${ }^{21}$. La música y la danza constituyen dos de los componentes esenciales en la esfera de los rituales de tránsito y las ceremonias cívicas o religiosas del Mediterráneo antiguo y los iberos no son una excepción. Forman parte inherente del ambiente ritual o festivo ${ }^{22}$. El aulós aparece ligado en Grecia al «estilo de vida» aristocrático -en el symposium, los juegos de palestra, las escenas teatrales - y los ritos religiosos -fiestas de matrimonio, funerales-. En Iberia la doble flauta se vincula a contextos sacros o ambientes de culto (La Serreta de Alcoy), funerarios (El Cigarrejo de Mula) o urbanos (San Miguel de Liria). La música, según se ha visto en Liria en algunos ejemplos, adopta un valor de memoria histórica, un ambiente de aedos (Aranegui, 1997). La danza, por

${ }^{21}$ En un fragmento cerámico de La Alcudia de Elche (Alicante) se ha visto una representación de danza complementada con hojas de palma (Castelo, 1990, fig. 16). Otras representaciones de danzas peor conocidas han sido atribuidas para algún otro ejemplo cerámico contestano de La Alcudia (Blázquez, 1997), o El Monastil de Elda en Alicante (Lucas, 1975). Algunas de estas danzas colectivas ibéricas se han asociado, en ocasiones, a la propiciación de la fecundidad o fertilidad, de la naturaleza y del hombre (Castelo, 1990, 39).

22 Ya en el Próximo Oriente antiguo y Egipto se documenta la presencia de flautistas, bailarines y cantantes participando en este tipo de ceremonias (Franckfort, 1939, pl. XVa; Starr, 1978, 403, n.p.p. 10). En la Grecia arcaica, el aulós es el instrumento del pathos en los ritos funerarios y las orgías dionisíacas. La melodía de la flauta, además, se asocia al trance y el delirio de los ritos, las danzas de posesión y los mitos (Vernant, 1986, 58), con estrecha vinculación al desarrollo del culto (Nordquist,1994). Especialmente destacable es el valor del aulós y las danzas en ceremonias iniciáticas de las y los jóvenes -paides y parthenoi- (Brelich, $1969,32,38,69,145,175 \ldots)$ otro lado, en el Mediterráneo antiguo ha sido definida como la respuesta física a emociones de alegría, tránsito o devoción cuya cualidad esencial es el ritmo, pautado por la melodía musical (Johnstone, 1956, 2-10). Las danzas ibéricas ${ }^{23}$ son conocidas sobre todo a través de la iconografía (Ruano, 1977; Lucas, 1979; Castelo, 1990; Blázquez, 1997; Aranegui, 1997). Las danzas ibéricas forman parte de celebraciones públicas, competiciones, cortejos de guerreros o ritos nupciales ${ }^{24}$. Sólo en el ejemplo de El Cigarralejo o Torredonjimeno (vid. supra) se relacionan, acompañadas de música, con ceremonias fúnebres. Tampoco se conocen danzas de tipo orgiástico ni dionisíaco ${ }^{25}$. No se conocen danzas individuales, sino colectivas. El fragmento cerámico de Almazora viene a sumarse a la iconografía de la danza ibérica y mediterránea. El personaje masculino que hemos presentado danza al son de la música de la doble flauta que tañe una mujer frente a él, mostrando la palma de una mano y elevando la pierna derecha. Pero esta imagen ofrece la particularidad de una naturaleza híbrida que proyecta rasgos animales. Más allá de la escena en cuestión, el tema de transformación o «disfraz» hombre/animal es conocido en ambientes del Mediterráneo antiguo. En Grecia ${ }^{26}$, por ejemplo, a partir del siglo vi a.C. entre las representaciones de danza, contamos con escenas de kômos con personajes disfrazados de animales como los hombres-caballo, con máscara y cola de animal, frente a una auletris, hombres-toro y hombres-pájaro, que se irán multiplicando con el auge de las representaciones teatrales (DelavaudRoux, 1995, 119 y ss.).

${ }^{23}$ La danza antigua es particularmente bien conocida en el mundo griego (Delavaud-Roux, 1994 y 1995), en su expresión cívica, pacífica, guerrera y dionisíaca.

${ }^{24}$ Estrabón (III, 3, 7), a inicios de nuestra era, cita la existencia de danzas en la Bastetania en las que participan hombres y mujeres.

25 Sin duda, donde el fenómeno de la danza es mejor conocido es de nuevo en Liria, donde se han documentado tres sistemas representativos diferentes (Aranegui, 1997a): al modo de un relato con músicos y bailarines - tal vez una reproducción de mitos en relación con los orígenes de la ciudad evocados a través de celebraciones-, a través de competiciones guerreras al ritmo de la música o, finalmente, en cortejos y procesiones.

${ }^{26} \mathrm{La}$ iconografía de la naturaleza híbrida, humana y animal, ya se documenta en el Próximo Oriente antiguo (Franckfort, 1939, 43, 68, 76...) donde son conocidas representaciones de hombres-toro -a menudo itifálicos-, hombres-león, pájaro o escorpión. Se trata, por tanto, de un viejo tema de ambiente, inicialmente oriental, con arraigo en el Mediterráneo. Incluso podríamos evocar el pasaje de la Odisea en el que la maga Circe transforma mágicamente a los compañeros de Ulises en cerdos (Odisea, X, 238-244), tema que en la iconografía de los vasos griegos evoluciona en representaciones de jabalíes, perros, carneros, toros o bueyes (Touchefeu-Meynier, 1968, 81-132). 
Los componentes que entran en juego en la escena que presentamos aquí inducen a considerarla dentro de una ceremonia ibérica, y mediterránea, festiva o ritual. El varón, caracterizado como animal, danza sólo - y tal vez, complementariamente, haría sonar algún tipo de instrumento musicalfrente a la flautista. Por vez primera estamos ante dos figuras afrontadas y no ante un desfile o cortejo por parejas o tríos mixtos. Se unen, por tanto, en este vaso de un contexto tardío tradiciones y temas de hondas raíces mediterráneas como la música y la danza ritual o el hombre-animal, a través de una escena única, donde se funden en perfecta armonía lo femenino y lo masculino, el sonido de la flauta y la ejecución rítmica de un paso de danza; la naturaleza humana y la animal, tal vez con un fin propiciatorio de fecundidad colectiva $o$, sin necesidad de evocar un tema mítico-religioso, con un interés más bien lúdico o festivo.

\section{VASO CON INSCRIPCIÓN PINTADA}

La inscripción pintada figura sobre la pared externa del borde de una cílica-esquifo del tipo VI.2 de Bonet y Mata, de 11,2 cm de diámetro (figs. 14 y 15). Está incompleta en ambos extremos a causa de la fractura de la pieza y su extensión conservada es de $6 \mathrm{~cm}$. El ductus es bastante seguro y regular. La altura de los signos es bastante uniforme: los núm. 1, 2, 3 y 5 miden $14 \mathrm{~mm}$, el núm. 4 mide 9 $\mathrm{mm}$ y el núm. 6 , incompleto, mide $11 \mathrm{~mm}$. La anchura de la pincelada oscila entre $1,1 \mathrm{~mm}$ y $2 \mathrm{~mm}$, aunque en el extremo superior del segundo signo llega a $3,4 \mathrm{~mm}$

El primer signo figura incompleto, pues la fractura de la pieza lo secciona verticalmente casi por su mitad; posiblemente se trata de $r v$, aunque no puede descartarse que sea una $a^{27}$. El segundo signo es un trazo vertical ligeramente inclinado a la izquierda, más grueso en su extremo superior, que se identifica claramente con el silabograma $b a$. La lectura del tercero, de trazado ligeramente asimétrico, es también segura, pues se trata del también silabograma $t i$. El cuarto, en cambio, se conserva completo pero está claramente inacabado y puede ofrecer alguna duda, aunque posiblemente se trata de $r$. La lectura del quinto es igualmente segura: $u$. Sigue un signo de puntuación representado por dos puntos dispuestos verticalmente y separados $5 \mathrm{~mm}$. El sexto y último está igualmente incompleto y resulta más dudoso;

27 Agradecemos los comentarios y sugerencias de J. Velaza (Universitat de Barcelona) y P. P. Ripollès (Universitat de València).
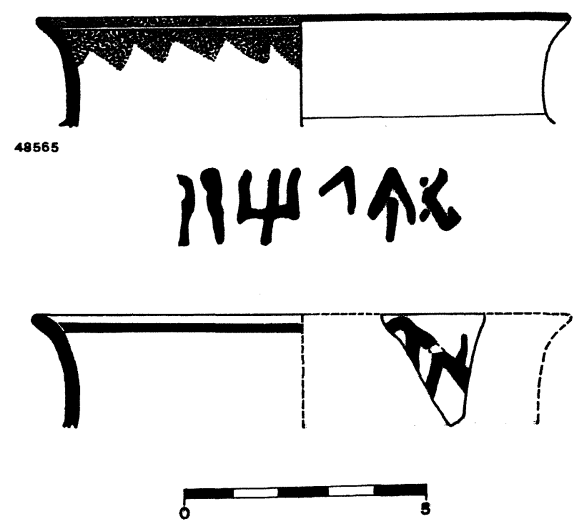

Fig. 14.- Vaso ibérico con inscripción pintada.



Fig. 15.-Vaso ibérico con inscripción pintada. (Foto G. Clausell).

parece quedar cerrado por su derecha con un trazo vertical, con lo que se trataría de $r$ o te. Las palabras que comiencen por $r$ son escasas, por lo que parece más probable que se trate de $t e$.

Según la interpretación de los signos propuesta, la lectura del breve texto conservado es la siguiente: ---]rvbatiru:te[---. El signario utilizado es el ibérico nororiental y las formas de los signos son las habituales en éste. En total han sido identificados 6 signos, de los cuales dos son inseguros. Su adscripción a la clasificación numeral de Untermann (MLH III, 1, 246-247) es la siguiente: $r v 5, b a 1, t i 1, r 1, u 1$ y $t e 4$. Con respecto a las recientes propuestas de datación paleográfica de Rodríguez Ramos (1997), pueden incluirse cuatro signos: $r v-1 b, b a-2, t i-1$ a y $t e-4$. La forma $r v-1 \mathrm{~b}$ es clásica y perdura al menos hasta el siglo II a.C.; la forma ba-2 aparece en el siglo III y perdura hasta el I a.C.; la forma $t i$-1a es clásica y presenta una cronología amplia; y la forma te-4 aparece en el siglo III y perdura hasta el I a.C. En conclusión, el signario presente en el texto del Torrelló adopta en parte formas clásicas que presentan una cronología amplia; sólo las formas $b a-2$ 
y te-4 permiten una mayor precisión cronológica a partir del siglo III a.C. La datación paleográfica, por tanto, es simplemente aproximativa. Es el estilo decorativo al que se asocia la presencia de textos pintados el que permite una mayor precisión a partir de mediados del siglo III a.C.

La presencia de un signo de puntuación permite distinguir en el texto dos palabras: de la primera nos falta el principio y de la segunda tan sólo tenemos el primer signo incompleto $\mathrm{y}$, por tanto, dudoso, aunque podría ser te. Las posibilidades de estudio ante un texto incompleto en ambos extremos son muy reducidas. La primera evidencia es que constaba al menos de dos palabras, pero no podemos avanzar más en el análisis de su estructura. Al final de la primera palabra podemos aislar el morfo $-u$. En el caso de la segunda, al ser su primer signo de lectura insegura las posibilidades son muy amplias y todas igualmente hipotéticas.

La consideración de que la primera palabra está incompleta no descansa únicamente en el hecho de que la pieza esté rota y el letrero incompleto, sino que hay otra razón de tipo lingüístico: la secuencia $r v b a$ - según la lectura más probable - no constituye nunca el principio de un lexema ${ }^{28}$, pues necesita apoyo vocálico. De esta manera puede considerarse que falta al menos un primer signo que completaría una secuencia bisilábica. Su restitución más probable és $t a$, pues el grupo rvba va precedido frecuentemente de $t a$ - formando el elemento tarvba ${ }^{29}$. Con ello nos encontraríamos con un segmento $\left[i^{---t a] r v b a}\right.$, que se da con cierta frecuencia en nombres personales (NP), lo que no debe llevarnos necesariamente a la consideración de que nos encontramos ante uno de ellos. De esta manera, su lectura parcialmente restituida puede quedar de la siguiente forma: $\left[i^{---t a}\right] r v b a t i r+u$.

El sufijo tarv es bien conocido en el léxico ibérico (Siles, 1985, 188). Aparece en la antroponimia ibérica, vasca y aquitana y se utiliza para la formación de étnicos ${ }^{30}$. Untermann (MLH III, 1, 176, § 547), señala que —además de ser un elemento antroponímico - figura como paradigma nominal. Para Silgo (1994, 127-129) parecen existir un lexe-

${ }^{28}$ Así lo encontramos en [---]rvbabiau (C.2.39, Ullastret) y [---]rvbal (E.1.67: Azaila).

${ }_{29} \mathrm{Su}$ restitución como [a] rvba, [i]rvba, [u]rvba o $[k a] r v b a$ es poco probable por ser estas secuencias muy poco frecuentes Las cuatro aparecen sólo en una ocasión cada una: arvba[---] (Velaza, 1991, núm. 48, Pech Maho); irvban (B.1.258, Ensérune); urvbai (F.13.65, Llíria) y [---]karvba [---] (Velaza, 1991, núm. 687, La Vall d'Uixó).

${ }^{30}$ Cf. Caro Baroja, 1954, 790-791; Albertos, 1966, 272 ; Palomar, 1960, 385; Michelena, 1979, 35; Tovar, 1979, 483485 . ma y un sufijo homófonos pero diferentes semánticamente. Seguido de $b a$ aparece en diversas ocasiones en el elemento antroponímico tarvban (MLH III, $1,233, \S 7.116)^{31}$.

El segmento -tir es muy poco frecuente en el léxico ibérico y no está documentado con seguridad en la antroponimia (Siles, 1985, 201; Silgo, 1994, 143). Lo econtramos en Azaila y Solsona (D.5.10 y E.1.404: tir) y en Alcoy (G.1.1, B-1: basvirtir). La posibilidad de que este segmento vaya unido al anterior signo formando el elemento -batir, que aparece en varios segmentos del plomo del Castell de Palamós (MLH III, 2, 82-83, C.4.1, 1-6) y en Ullastret $(\mathrm{C} .4 .1,4)$, y cuya categoría gramatical o información léxica es desconocida (Velaza, 1991, núm. 148 ), no es muy segura porque en el primer caso parece tratarse de una palabra completa, algo que aquí no sucede según puede deducirse de la falta de puntuación. En cuanto a bati, aparece por dos veces como abreviatura de NP o marca de propiedad en Ensérune (B.1.100) y Azaila (E.1.89-90). Por otra parte, batibi figura también en Ullastret (C.2.3A, 6).

Finalmente, el morfo - $u /$ - $i u$ es ampliamente conocido en el léxico ibérico y ha sido estudiado en repetidas ocasiones ${ }^{32}$. Untermann (MLH III, 1, 179 , $\S 553$ ) aisla este elemento en secuencias de posible concordancia: 1) con antropónimos; 2) con palabras de categoría desconocida; y 3 ) con una palabra sufijada por $-k u$.

\section{VALORACIONES FINALES}

La excavación del asentamiento del Torrelló del Boverot de Almazora, de dimensiones reducidas y larga perduración, situado junto al cauce del río Mijares, plantea el problema del aprovechamiento del espacio y la superposición de estructuras de hábitat de época diversa. En este trabajo se ha documentado, a través de unas singulares cerámicas ibéricas, el momento final de la vida del poblado, en el período Ibérico tardío. El estudio de estos vasos singulares ha proporcionado indicios de la relación del asentamiento con destacados centros urbanos ibéricos del País Valenciano, como el cerro de San Miguel de Liria. La escena con flautista y danzante del Torrelló presenta un referente con las cerámicas de

${ }^{31}$ Caspe (E.13.1: svor tarban), Canet lo Roig (F.2.2: tarvban ikorv), Yátova (F.20.3: tautin tarban), Ampurias (C.1.5.: belesv ta(rv)ban) y en la Turma Salluitana (tarban $t u$, por Tabbantu). Por otra parte, en un texto pintado de Llíria figura seguido de $r$ (F.13.41: .Jtarvbarinirv).

32 Palomar, 1960, 386; Michelena, 1979, 36; Velaza, 1991, 128; Silgo, 1994, 247 
Liria en lo que se refiere al seguimiento de la técnica de figuras planas, la composición y ejecución general, a pesar de la inferior calidad del vaso castellonense en relación con los vasos edetanos. Este paralelismo con algunas producciones de Liria podría orientar la cronología del fragmento, teniendo en cuenta, además, la existencia en el Torrelló de letreros pintados en vasos cerámicos, como en Edeta. La datación del vaso con decoración figurada de Almazora se apoyaría, por tanto, en las fechas proporcionadas por las cerámicas de Liria, la cronología de otras escenas figuradas del territorio de Castellón de época tardía ( $c f$. infra), sin olvidar el arco cronológico orientado por las cerámicas de importación halladas en el propio yacimiento estudiado (siglo III-mediados del siglo II a.C.).

A propósito de la relación «territorio-iconografía», se ha de insistir en la creciente documentación de yacimientos ibéricos con cerámicas figuradas en distintas comarcas de la provincia de Castellón, a pesar de su escasez general, como La Torre d'Onda de Burriana, El Solaig de Bechí, el Castell de la Vilavella, La Punta de La Vall d'Uixó, el Mas de Víctor de Rosell o el Puig de la Misericordia de Vinaroz ( $c f$. supra), siendo únicamente La Torre de Onda y El Solaig, además del Torrelló, los asentamientos que han proporcionado escenas humanas, con jinetes en el caso de los dos primeros, y el tema de la música y la danza en el fragmento estudiado de Almazora. No hemos de olvidar que en la necrópolis de este mismo yacimiento, formando parte del ajuar de la tumba núm. 20, se documentan piezas cerámicas con decoraciones singulares -con policromía y temas vegetales - lo que sugiere la existencia de vasos de encargo, tanto para la necrópolis, como también en el poblado.

Con respecto a la temática de la escena con figuración del asentamiento, sin ser un unicum en los repertorios iconográficos ibéricos —conocemos flautistas y danzantes en vasos con decoraciones pintadas complejas-, sí que se puede calificar como singular por su composición, en referencia a la representación de danzas ibéricas, puesto que por vez primera se presentan dos figuras afrontadas una tocando la flauta y otra danzando- y no un desfile o un cortejo por parejas o tríos mixtos, como es habitual en el corpus de Liria por ejemplo, donde el tema está perfectamente estudiado. Los rasgos del personaje masculino de Almazora son también singulares, especialmente la descripción de su cuerpo, el tocado de crines, y sus atributos. Se muestra una naturaleza híbrida, humana y animal. Finalmente, los rasgos del personaje femenino son asimismo particulares — su tocado y elementos asociados-, permaneciendo la incógnita del motivo que sobresale por su parte posterior. Se ha propuesto, en definitiva, la interpretación de esta escena ibérica de época tardía, dentro del ambiente del Mediterráneo, como la representación de una ceremonia festiva o ritual. El sonido del aulós parece atraer y guiar los pasos del ser —el hombre/la fiera- que aparece danzando frente a la flautista, surgiendo de una metáforica puerta o «jaula». Es posible una complementariedad de significados en esta excepcional imagen, tal vez lúdica ¿o teatral incluso? que, al mismo tiempo, podría evocar un antiguo rito o tradición ritual.

Con respecto al vaso con letrero estudiado, se trata de la tercera inscripción ibérica pintada conocida en las comarcas castellonenses, y concretamente la primera en la comarca litoral de La Plana. Hacia el norte se conocía, cerca del llano litoral de Vinaroz, la de La Curolla de Cervera del Maestre (Fletcher, 1972, 106-107; Siles, 1985, 383, núm 1744; F.11). Hacia el sur, en el interior del valle del Palancia, encontramos la de la Torre del Mal Paso de Castellnovo (Fletcher, 1954, 208, fig. 17; Fletcher, 1985, 24, fig. 23, 2; F.10.1). En el llano litoral conocemos una en Sagunto (F.11.17). Los textos pintados son característicos de la cerámica de Liria/Edeta, donde se conocen un total de 96 (Fletcher, 1985, 9-16, núm. 1-92, fig. 1-19; F.13.3-70; Bonet, 1995, 451459), y de los asentamientos de su territorio, como La Monravana (Fletcher, 1985, 17, fig. 21, 1-2; F.12.1) y La Torre Seca (Fletcher, 1985, 17-18, fig. 21,$3 ;$ F.25.1). Su presencia en la decoración pintada de la cerámica de Liria le valió a ésta la denominación de estilo narrativo. También aparecen en el interior de las comarcas centrales del País Valenciano, en Los Villares de Caudete de las Fuentes (Fletcher, 1985, fig. 21, 4-5; Mata, 1991, 178-179; F.17.6-7).

Presentamos, en conclusión, dos piezas cerámicas representativas del horizonte del Ibérico tardío, que testimonian el momento final de un poblado, el Torrelló del Boverot de Almazora, cuya investigación depara prometedores resultados.

\section{BIBLIOGRAFÍA}

Abreviatura:

MLH III Monumenta Linguarum Hispanicarum: Untermann, J. (1990): Monumenta Linguarum Hispanicarum. III. Die iberischen Inschriften aus Spanien. Wiesbaden.

Albertos Firmat, M. L. (1966): La onomástica personal primitiva de Hispania Tarraconense y Bética. Salamanca. 
Aranegui, C. (ed.), (1997): Damas y caballeros en la ciudad ibérica: las cerámicas de Llíria (Valencia). Cátedra. Historia/ Serie Menor. Madrid.

Arasa, F. (1987): L'època romana, en Borriana en su Historia, I, 43-59. Borriana.

ARASA, F. (1995): Territori i poblament en l'epoca romana a les comarques septentrionals del litoral valencià (manuscrito). Tesis Doctoral. Universitat de València.

Ballester, I., Fletcher, D., Pla, E., Jordá, F. y AlCÁCER, J. (1954): Corpus Vasorum Hispanorum. Cerámica del Cerro de San Miguel de Liria. Madrid.

BlÁzQuez, J. M. (1983): Religiones prerromanas. Primitivas religiones ibéricas II. Madrid.

BlázQuez, J. M. (1997): Música y danza en la religión de los pueblos prerromanos de la Península Ibérica. Estética y religión. El discurso del cuerpo y los sentidos. A. Vega, J. A. Rodríguez y R. Bouso (Eds.), 405-418, Madrid.

Bonet, H. y Mata, C. (1981): El Puntal dels Llops (Olocau, Valencia). Serie de Trabajos Varios del S.I.P. Valencia.

Bonet, H. y Mata, C. (1997): La cerámica ibérica del siglo v a.C. en la Edetania. Recerques del Museu d'Alcoi, 6, 31-47.

Bonet, H. (1995): El Tossal de Sant Miquel de Llíria. La antigua Edeta y su territorio. S.I.P. Centre Cultural La Beneficència. Valencia.

Brelich, A. (1969): Paides e Parthenos. Roma.

Caro Baroja, J., (1954): La escritura en la España prerromana (Epigrafía y Numismática), Historia de España dirigida por D. Ramón Menéndez Pidal, I, 3, 679-812. Madrid.

Castelo, R. (1989): La música en la Antigüedad hispana. 1. «El aulós y diaulós». Boletín de la Asociación Española de Amigos de la Arqueología, 26, enero-junio, 9-18.

CAstelo, R. (1990): Aproximación a la danza en la antigüiedad hispana. Manos entrelazadas, Espacio, Tiempo y Forma, $H^{a}$ Antigua, Serie II, 3, 1942.

CHAPA, T. (1985): La escultura ibérica zoomorfa. Ministerio de Cultura. Madrid.

Clausell, G. (1995): Nuevos hallazgos fenicios en la provincia de Castellón. Quaderns de Prehistòria i Arqueologia Castellonenses, 16, 83106.

Clausell, G. (1997): Materiales del Bronce Medio en el Torrelló del Boverot Almassora (Castellón). La Murà. Revista del Museu Municipal d'Almassora, 21-31.

Clausell, G. (1998): El comercio marítimo fenicio en la desembocadura del río Mijares (Castellón). Actas de las III Jornadas de Arqueología Subacuática (Valencia 1997), 237-247. Valencia.

Clausell, G. (1999a): El comienzo de la iberización: el Torrelló del Boverot (Almazora Castellón). QPAC 19, 181-192.

Clausell, G. (1999b): Clausell Cantavella, G. (1999): La incineración 20 de la necrópolis del Torrelló del Boverot d'Almassora(Castellón). XXV C.N.A., 95-500.

Conde, M. ${ }^{a}$ J. (1992): Una producció ceràmica caracteristica del mon iberic tardà: el Kalathos «barret de copa». Fonaments, 8, 117-169.

Cuadrado, E. (1990): Un nuevo análisis de la crátera ibérica del desfile militar de El Cigarralejo (Murcia). Homenaje a Jerónimo Molina, 131134. Murcia.

Delavaud-Roux, M.-H. (1994): Les danses pacifiques en Grece Antique. Université de Provence. Aix-en-Provence.

Delavaud-Roux, M.-H. (1995): Les danses dionysiaques en Grece Antique. Université de Provence. Aix-en-Provence.

Fernández Izquierdo, A. (1995): Presencia de Kalathoi en yacimientos submarinos valencianos. $\mathrm{Sa}$ guntum-P.L.A.V., 29, 123-129.

FLeTCHER, D. (1954): La cueva y el poblado de la Torre del Mal Paso (Castellnovo-Castellón), Archivo de Prehistoria Levantina, V, 187-223. Valencia.

FLETCHER, D. (1972): Nuevas inscripciones ibéricas de la región valenciana, Archivo de Prehistoria Levantina, XIII, 103-126. Valencia.

FleTCHer, D. (1980): Los plomos ibéricos de Yátova (Valencia), Serie de Trabajos Varios del S.I.P., 66. Valencia.

Fletcher, D. (1985): Textos ibéricos del Museo de Prehistoria de Valencia, Serie de Trabajos Varios del S.I.P, 81. Valencia.

FrankFORT, H. (1939): Cylinder Seals. A documentary Essay on the Art and Religion of the Ancient Near East. London.

García y Bellido, A. (1943): Algunos problemas del arte y cronología ibéricos. AEspA., XVI, 50, 78-108.

IZQUIERDo, I. (1995): Un vaso inédito con excepcional decoración pintada procedente de la necrópolis ibérica de Corral de Saus (Moixent, Valencia). Saguntum-PLAV, 29, Homenatge a la Pra. Dra. Milagro Gil-Mascarell Boscá, I, 93-104.

Johnstone, M. A. (1956): The Dance in Etruria. A comparative study. Ed. L. S. Olschki. Florence.

Llobregat, E. A. (1972): Contestania ibérica. IEA. Alicante. 
Maestro, E. (1989): Cerámica ibérica decorada con figura humana. Monografías Arqueológicas, 31. Universidad de Zaragoza.

Marco, F. (1990): Las esculturas de La Albelda de Litera (Huesca). Zephyrus, XLIII, 329-338.

Mata, C. y Bonet, H. (1992): La cerámica ibérica: ensayo de tipología. Homenaje a Enrique Pla Ballester, Serie de Trabajos Varios del S.I.P., 89, 117-173.

Mata, C. 1991: Los Villares (Caudete de las Fuentes, Valencia). Origen y evolución de la cultura ibérica, Serie de Trabajos Varios del S.I.P, 88. Valencia.

Mesado, N. (1974): Vinarragell (Burriana, Castellón). Origen y evolución de la cultura ibérica, Serie de Trabajos Varios del S.I.P. 46. Valencia.

Mesado, N. y SARRIón, I.(2000): Un enterramiento insólito: el caballo ibérico de La Regenta. Commemoració del XXX Aniversari del Museu Arqueològic Comarcal de la Plana Baixa de Burriana (1967-1997), 89-101. Col. Papers, $3^{\mathrm{a}}$ época, 20. Burriana.

Michelena, L. (1979): La langue ibère, Actas del II Coloquio sobre lenguas y culturas prerromanas de la Península Ibérica, 23-39. Salamanca.

Nicolini, G. (1973): Les Ibéres. Art et civilisation. Fayard, París.

Nordquist, G. C. (1994): Some notes on musicians in Greek cult En Hägg, R. (1994): Ancient Greek cult practice from the epigraphical evidence. Proceedings of the second International Seminar on ancient Greek Cult (Atenas, 1991). Acta Instituti Atheniensis Regni Sueciae, $8^{\circ}$, XIII, 81-93. Estocolmo.

NoRdSTRÖM, S. (1969-1973): La céramique peinte ibérique de la province d'Alicante, I y II. Acta Universitatis Stockholmiensis. VI y VIII. Estocolmo.

Oliver, A. (1994): El poblado ibérico del Puig de la Misericordia de Vinaroz. Associació Cultural Amics de Vinarós. Castellón

Olmos, R. (dir.) (1992): La sociedad ibérica a través de la imagen. Catálogo de la exposición, Centro Nacional de Exposiciones. Ministerio de
Cultura. Dirección General de Bellas Artes y Archivos. Madrid.

Olmos, R. (1987): Posibles vasos de encargo en la Cerámica ibérica del Sureste. AEspA., 60, 21-42.

PALOMAR, R. (1960): Antroponimia prerromana, Enciclopedia Lingüística Hispánica, I. Antecedentes. Onomástica, 347-387. Madrid.

Pascual, J.Ll. y García Puchol, O. (1998): El asentamiento prehistórico del Sitjar Baix (Onda, Castelló). Saguntum-P.L.A.V., 31, 63-78.

Pedro, M. ${ }^{a}$ J. de (1998): La Lloma de Betxí (Paterna, Valencia). Un poblado de la Edad del Bron$c e$. València. Serie de Trabajos Varios del S.I.P., Valencia.

RodRíGuez Ramos, J. (1997): Primeras observaciones para una datación paleográfica de la escritura ibérica, AespA., 70, 13-30.

Rouillard, P. (1997): Antiquités de l'Espagne, Louvre et Saint Germain-en-Laye. Musée du Louvre. RMN. Paris.

RuANo, E. (1977): La danza en la antigüedad hispánica y el mundo clásico, BAEAA, 8, 44-48.

RuANo, E. (1987): La escultura humana de piedra en el mundo ibérico. Madrid.

SANFEliu, T. (1985): El relieve. La provincia de Castellón de la Plana. Tierras y Gentes. Castellón.

Sanmartí, J., Bruguera, R. y Morer, J. (1998): Les àmfores ibèriques a la Catunya meridional. Quaderns de Prehistoria i Arqueología de Castelló, 19, 267-289.

Siles, J. (1985): Léxico de inscripciones ibéricas. Madrid.

Silgo, L. (1994): Léxico ibérico. Valencia.

TOuChefeu-Meynier, O. (1968): Thèmes Odysseéens dans l'art antique. De Boccard. Paris.

Tovar, A. (1979): Notas lingüísticas sobre monedas ibéricas, Actas del II Coloquio sobre lenguas y culturas prerromanas de la Península Ibérica, 473-480. Salamanca.

Velaza, J. (1991): Léxico de inscripciones ibéricas (1976-1989). Barcelona.

Vernant, J.-P. (1986): La mort dans les yeux. Figures de l'Autre en Grèce ancienne. Artémis, Gorgô. Hachette. Paris. 


\title{
ANEXO \\ ESTUDIO DE CONTENIDOS EN CERÁMICAS IBÉRICAS DEL TORRELLÓ DE ALMAZORA (CASTELLÓN)
}

\author{
JORDI JUAN-TRESSERRAS \\ Universitat de Barcelona
}

En el marco del programa de intervenciones arqueológicas realizadas en el Torrelló de Almazora (Castellón) y dirigidas por Gerardo Clausell se efectuó una selección de muestras cerámicas para su posterior análisis de contenidos en el marco de un estudio global del yacimiento. El principal objetivo fue utilizar una metodología adecuada a la recuperación de la máxima información posible, estableciendo para ello un modelo sistemático de recogida y tratamiento de muestras que nos pudieran ofrecer información especialmente sobre la funcionalidad de los espacios objeto de estudio.

En total se analizaron 19 recipientes cerámicos, efectuándose el análisis de treinta y ocho muestras, diecinueve para la caracterización de residuos microscópicos y diecinueve para el estudio de indicadores químicos y bioquímicos.

\begin{tabular}{|l|l|l|}
\hline Muestras & \multicolumn{1}{|c|}{ Siglas } & \multicolumn{1}{c|}{ Descripción } \\
\hline M-1 & TA.95 & Residuos interior cálato \\
M-2 & TA.95 $\mathrm{n}^{\circ} 45117$ & Residuos interior cálato \\
M-3 & TA.95 $\mathrm{n}^{\circ} 45092$ & Residuos interior cálato \\
M-17 & TA.95 $\mathrm{n}^{\circ} 38335$ & Anfora ibérica \\
M-18 & TA.95 $\mathrm{n}^{\circ} 40056$ & Anfora ibérica \\
\hline
\end{tabular}

Tabla 1.-Muestras analizadas.

En el caso del yacimiento de El Torrelló del Boverot se han efectuado diferentes técnicas para la identificación de residuos: observación microscópica combinada en lupa binocular, microscopía óptica con contraste de fase de Zernike y microscopía electrónica de barrido con microanalizador de rayos $\mathrm{X}$ (EDS) incorporado, y la técnica combinada de cromatografía de gases y espectrometría de masas.

\begin{tabular}{|c|c|c|c|}
\hline Muestra & Siglas & Descripcion & Contenidos \\
\hline M-1 & TA. 95 & Residuos cálato & $\begin{array}{l}\text { Indicadores: ácido cerótico, fitolitos de frutos carnosos (Ficus cari- } \\
\text { ca), diatomeas } \\
\text { Posible interpretación: miel con frutos carnosos }\end{array}$ \\
\hline M-2 & $\begin{array}{l}\text { TA. } 95 \\
\mathrm{~N}^{\circ} 45117\end{array}$ & Residuos cálato & $\begin{array}{l}\text { Indicadores: ácido cerótico, fitolitos de frutos carnosos, diatomeas } \\
\text { Posible interpretación: miel con frutos carnosos }\end{array}$ \\
\hline M-3 & $\begin{array}{l}\text { TA. } 95 \\
\mathrm{~N}^{\circ} 45092\end{array}$ & Residuos cálato & $\begin{array}{l}\text { Indicadores: ácido cerótico, fitolitos de frutos carnosos, diatomeas } \\
\text { Posible interpretación: miel con frutos carnosos }\end{array}$ \\
\hline M-17 & $\begin{array}{l}\text { TA. } 95 \\
\text { N}^{\circ} 38335\end{array}$ & Ánfora ibérica & $\begin{array}{l}\text { Indicadores: granos de almidón gelatinizados y alterados, fitolitos, } \\
\text { levaduras, oxalato. } \\
\text { Posible interpretación: cerveza }\end{array}$ \\
\hline M-18 & $\begin{array}{l}\text { TA. } 95 \\
\mathrm{~N}^{\circ} 40056\end{array}$ & Ánfora ibérica & $\begin{array}{l}\text { Indicadores: granos de almidón gelatinizados y alterados, fitolitos, } \\
\text { levaduras, oxalato. } \\
\text { Posible interpretación: cerveza }\end{array}$ \\
\hline
\end{tabular}

Tabla 2.--Relación de resultados.

\section{Muestras 1, 2, y 3: miel con frutos carnosos}

El estudio microscópico de los residuos del recipiente proporcionó una importante concentración de fitolitos correspondientes a esclereidas de frutos carnosos. Por otro lado el estudio del residuo por cromatografia de gases/espectrometría de masas constató la presencia de compuestos característicos 
de la cera de abeja. La combinación de los dos resultados nos permitió relacionar el producto contenido con una preparación de frutos carnosos en miel o en un arrope. Ambas preparaciones se empleaban en el proceso de la preparación del vino. En la muestra del contenido se identificaron restos de tejidos y esclereidas características de los higos ( $\mathrm{Fi}$ cus carica L.). Estos restos son escasos en los yacimientos peninsulares, según Buxó (1997), las únicas referencias corresponden a los yacimientos del Neolítico Medio de la Bassa (Fonteta, Girona)(Tarrus et alii 1982) y de la edad del Hierro en la Illa d'En Reixac (Ullastret, Girona, Castro y Hopf, 1982). A éstos datos tenemos que añadir los macrorrestos y semillas identificadas en la cella vinaria de la zona de elaboración de vino de Barcino (Juan-Tresserras 1998) y el puerto romano de Irún (Peña-Chocarro y Zapata 1997).

\section{Muestras 17, 18 y 19: cerveza}

La identificación de los residuos de cerveza se ha basado en trabajos anteriores (Samuel 1996; Maksoud et alii. 1994; Juan-Tresserras 1996, 1997a, 1997b, 1998 entre otros). Los granos de almidón identificados presentan alteraciones de molido, así como evidencias del malteado de los granos de cereal. La germinación produce alteraciones características en los granos de almidón producto del ataque enzimatíco: la alteración de la superficie del grano que presenta hoyos, incluso canales, producidos por las enzimas a-amilasa, pudiendo observar en algunos casos las lamella en los granos parcialmente digeridos (Palmer 1995). Por otro lado, la gelatinización del almidón que aparece formando una película sólida en la que se pueden encontrar granos de almidón embebidos, indica que los cereales, o el producto de su procesado, fueron calentados estando húmedos, aunque el grado de calentamiento y nivel de humedad pueden ser variables (Samuel 1996). Las levaduras son características del proceso de braceado y fermentación. La identificación de oxalato se ha efectuado mediante la aplicación del test de Feigl, aunque existen otras técnicas más precisas como son la espectrometría de infrarrojos transformada de Fourier o el método ión-cromatográfico rápido.

\section{BIBLIOGRAFÍA}

Buxó, R. (1997): Arqueología de las plantas. Ed. Crítica. Barcelona.

Goertges, S. \& Schneider, F. (1979): Kristalle im Wein, Deutsche Weinbau 34 (2), 69-75.

Juan-Tresserras, J. (1997): Procesado y preparación de alimentos vegetales para consumo humano. Aportaciones del estudio de fitolitos, almidones y lípidos en yacimientos arqueológicos prehistóricos y protohistóricos. Dept. Prehistòria, Història Antiga i Arqueologia. Universitat de Barcelona. Tesis Doctoral (inédita).

Juan-Tresserras, J. (1998a): El cultivo de la vid y la elaboración del vino en la Península Ibérica en la Antigüedad. Aportaciones de los análisis de residuos, II Col.loqui Internacional d'Arqueologia Romana. El Vi a l'antiguitat: economia, producció $i$ comerç al Mediterrani Occidental. Actes (Badalona 6/9 de maig de 1998). Museu de Badalona. Monografies Badalonines, núm. 14, 87ss.

JuAN-Tresserras, J. (1998b): Estudio analítico de los residuos conservados en el interior de recipientes y asociados a materiales de molienda y trituración, XXII Col.loqui Internacional per l'Estudi de l'Edat del Ferro. Els productes alimentaris d'origen vegetal a l'edat del Ferro a l'Europa Occidental: de la producció al consum. Museu d'Arqueologia de Catalunya-AFEAF. Girona.

KoeHLer, H. y Miltenberger, R. (1981): Kristallbildung im Wein, Bayerisches Landwirtschaftliches Jarchbuch Sonderheft 58 (2), 54-69.

Michel, R. H.; McGovern, P. E. y Badler, V. R. (1993): The first wine and beer. Chemical detection of ancient fermented beverages, Analytical Chemistry 65 (8), 408-413.

PeÑa-Chocarro, L. y Zapata, L. (1997): Higos, ciruelas y nueces: aportación de la arqueobotánica al estudio del mundo romano, Isturitz 9, 679-690.

Stummer, A. (1911): Zur Urgeschichte der Rebe und des Weinbaues, Mitt.Anthropol.Ges. Wien 41, 283296.

TARrus, J.; Pons, E. y Chinchilla, J. (1982): La tomba neolítica de la Bassa (Fonteta, La Bisbal). Una nova evidència d'elements Chassey a Catalunya, Informació Arqueològica 34, 39-66. Barcelona.

Tyree, E. E. (1994): Phytolith analysis of olive and wine sediments for possible identification in archaeology, Canadian Journal of Botany 72, 499504. 